\title{
ACCOMMODATING THE NATIONAL EDUCATION POLICY IN PONDOK PESANTREN DDI MANGKOSO: STUDY PERIOD OF 1989-2018
}

\author{
Muhammad Alqadri Burga \\ Universitas Islam Negeri (UIN) Alauddin Makassar \\ e-mail:qadriburga@gmail.com \\ Azhar Arsyad \\ Universitas Islam Negeri (UIN) Alauddin Makassar \\ e-mail:azhar_arsyad@botmail.com \\ Muljono Damopolii \\ Universitas Islam Negeri (UIN) Alauddin Makassar \\ e-mail:muldafat@yahoo.com \\ A. Marjuni \\ Universitas Islam Negeri (UIN) Alauddin Makassar \\ e-mail: h.marjunij@yahoo.com
}

Submission : 20 February $2019 \quad$ Revised : 12 September 2019

Published: 15 September 2019

\begin{abstract}
This research was aimed at analyzing the 1) existence of the Pondok Pesantren DDI Mangkoso as a traditional Islamic educational institution; 2) the dynamic policy of national education in the period of 1989-2018; 3) various national education policy accommodating by the Pondok Pesantren DDI Mangkoso; and 4) varied obstacles and experienced by the pesantren in accommodating national education policy and the solutions. The results of this research show that the Pondok Pesantren DDI Mangkoso is still kept existing as a traditional Islamic educational institution by preserving five roles: a place transforming classical Islamic sciences, Da'wah institution, Islamic tradition conservationists, Islamic scholar generating center, and community service and empowerment. The position change of pesantren in the national educational policy during 1989 - 2018 implicates dynamiclally to the Pondok Pesantren DDI Mangkoso. The accommodation forms of national education policy conducting by the Pondok Pesantren DDI Mangkoso are classical system, national education curriculum implementation, and standardizing the learning process and educators. Some obstacles facing in accommodating these forms are like culture and organizational structure wrestling, limited resource, and lack of community participation. This research has implications for the importance of the accumulation of cultural values, religious values, and modern values in pesantren so that it can compete amid the progress of educational institutions in general.
\end{abstract}

Keywords: Accommodation, Curriculum Integration, Inclusive paradigm, National education policy, Pesantren.

\section{Abstrak}

Penelitian ini bertujuan untuk menganalisis 1) eksistensi Pondok Pesantren DDI Mangkoso sebagai representasi lembaga pendidikan Islam tradisonal; 2) dinamika kebijakan pendidikan nasional kurun waktu 1989-2018; 3) ragam kebijakan pendidikan nasional yang diakomodasi oleh Pondok Pesantren DDI Mangkoso; dan 4) ragam hambatan Pondok Pesantren DDI Mangkoso dalam mengakomodasi kebijakan pendidikan nasional beserta solusinya. Metode penelitian yang digunakan adalah kualitatif dengan pendekatan fenomenologi. Hasil penelitian menunjukkan bahwa Pondok. Pesantren DDI Mangkoso tetap eksis sebagai lembaga pendidikan Islam tradisional meski melakukan pengembangan yang sifatnya modern dengan mempertahankan lima peran, yaitu: Tempat transmisi ilmu-ilmu Islam klasik, lembaga dakwah, pelestari tradisi Islam, pusat reproduksi ulama, serta tempat pengabdian dan pengembangan masyarakat. Perubahan posisi pesantren dalam kebijakan pendidikan nasional kurun waktu 1989-2018 berimplikasi terhadap kebijakan pendidikan Pondok Pesantren DDI Mangkoso yang dinamikanya dibagi ke dalam tiga tahap, yaitu: transformasi kelembagaan, pemaduan kurikulum, dan penerapan paradigma inklusif berbasis budaya. Berbagai hambatan dalam akomodasi tersebut adalah pergumulan kultur dan struktur organisasi, keterbatasan sumber daya, dan minimnya partisipasi masyarakat. Penelitian ini berimplikasi pada perlunya 
akumulasi nilai tradisional, nilai agama, dan nilai modern oleh pesantren agar mampu bersaing babkan menjadi inspirasi di tengah kemajuan lembaga pendidikan pada umumnya.

Kata Kunci: Akomodasi, Integrasi kurikulum, Paradigma inklusif, Kebijakan pendidikan nasional, Pesantren.

\section{Background}

Pesantren is regarded as an Indonesian Muslim indigenous educational institution, thus it has highly strong roots in the community. This institution is a cultural product of Indonesia began since appearing the Islamic communities in the Indonesian archipelago. The held and maintained values by the pesantren are the cultural values of Indonesian people where the schools are existing. The local culture becomes the preserved tradition of the pesantren functioning as the characteristic of a traditional Islamic educational institution. ${ }^{1}$ The pesantren is not only merely an Islamic boarding school but also has five main elements distinguishing this kind of school to others such as 1) religious leader or teacher (Kiai), 2) mosque, 3) students (santri), 4) dormitory and 5) study of classical Islamic books $^{2}$. These five major elements are the existing spirits and indicators of pesantren's traditionality in the continuously growing modern community. Furthermore, the pesantren is synergically and integratively stimulated to change based on community development.

Trends of pesantren adapting the community development prove that it is not only an inclusiveness educational institution but also more inclusively through maintaining the inherited values inline with receiving various changes offering from outside by

${ }^{1}$ M. Amin Haederi, Masa Depan Pesantren: Dalam Tantangan Modernitas dan Tantangan Kompleksitas Global (Jakarta: IRD Press, 2006), p. 3.

2 Guntur Cahaya Kesuma, 'Refleksi Model Pendidikan Pesantren dan Tantangannya Masa Kini', Tadris: Jurnal Keguruan Dan Ilmu Tarbiyah, 2.1 (2017), 6779 < https://doi.org/10.24042/tadris.v2i1.1740>. Read too Zamakhsyari Dhofier, Tradisi Pesantren: Studi Pandangan Hidup Kyai dan Visinya Mengenai Masa Depan Indonesia (Jakarta: LP3ES, 2015), p. 79.
Islamic filters. ${ }^{3}$ The inclusivity of pesantren is seen that striving to protect the tradition of studying the classic Islamic book (kitab kuning) using a mengaji tudang method (cycle studying). The study of classic Islamic book using this method is not related to the classical system (school) and limited learning ending time. However, it is going gradually to be reflected receiving a better offering from the western educational system, which factually had adopted the classical system (school) ${ }^{4}$.

The acceptance of the pesantren regarding the classical system (school) leads to accommodate the national education policy into the pesantren's educational system ${ }^{5}$. This accommodation is an attempt to create alreadiness Muslim generation facing modernity challenges. ${ }^{6}$ Therefore, the pesantren consistently strives to conduct the educational system standardization based on the Acts No. 20 of 2003 regarding National Education System, The Government Regulation No. 13 of 2015 about the National Education Standard, and The Government Regulation No. 55 of 2007 about Religion

3 Syamsul Ma'arif, Pesantren Inklusif Berbasis Kearifan Lokal (Yogyakarta: Kaukaba Dipantara, 2015), p. 55 .

4 Ahmad Fauzi, 'Pendidikan Inklusif Berbasis Kearifan Lokal dalam Praktik Sosial di Pesantren Zainul Hasan Genggong Probolinggo Jawa Timur', in Proceedings of Annual Conference for Muslim Scholars, 2017, pp. 715-25.

5 Ahmad Saifuddin, 'Eksistensi Kurikulum Pesantren dan Kebijakan Pendidikan', Jurnal Pendidikan Agama Islam (Journal of Islamic Education Studies), 3.1 (2016), <https://doi.org/10.15642/pai.2015.3.1.207-234>.

${ }^{6}$ Nurcholish Madjid, Bilik-bilik Pesantren: Sebuah Potret Perjalanan (Jakarta: Dian Rakyat dan Paramadina, 2010), p. 7. 
Education, that should make improvements for many aspects ${ }^{7}$.

The research relating to the improvements of the pesantren as responding the modernization has been more conducted. However, those prior various research just only describe the tradition sustainability and transformation process of pesantren from salafiah to khalaf ${ }^{8}$. Studies regarding the national education policy accommodating by the pesantren only are focussed on curriculum implementation and being conceptualized as political education carrying out by the government and the management of pesantren'. The completeness of science study relating to repositing the roles of pesantren in adjusting the national education policies is not revealed yet according to the authors' willingness comprehensively. This study is crucial due to be an indicator of accumulating tradition and modernization in the Islamic Boarding School conductively through attempts to accommodate the national education policies and their implementation that should be conducted in the community to express this school as an Islamic educational institution.

7 Abd Halim Soebahar, Modernisasi Pesantren: Transformasi Kepemimpinan Kiai dan Sistem Pendidikan Pesantren (Yogyakarta: LKiS, 2013), p. 44.

8 Suparjo, 'Relasi Kiai-Santri di Pesantren Futuhiyyah, Demak', Ibda': Jurnal Kajian Islam Dan Budaya, $\quad 15.2 \quad$ (2017),192-214 <https://doi.org/10.24090/IBDA.V15I2.1335>.Ali

Asyhar, 'Model Transformasi Pendidikan Pondok Pesantren di Pulau Bawean Gresik', JOIES: Journal of Islamic Education Studies, 1.2 (2016), 277-302. Nur Jamal, 'Transformasi Pendidikan Pesantren dalam Pembentukan Kepribadian Santri', Tarbiyatuna: Jurnal Pendidikan Islam, 8.2 (2015), 64-100. Muhammad Hasan, 'Inovasi dan Modernisasi Pendidikan Pondok Pesantren', Karsa: Journal of Social and Islamic Culture, 23.2 (2015), 296-306

<https://doi.org/10.19105/karsa.v23i2.728>

9 Ainna Khoiron Nawali, 'Dampak Penerapan

Kurikulum Kementerian Agama dan Kurikulum Pesantren terhadap Peningkatan Hasil Belajar Pendidikan Agama Islam di Madrasah Aliyah Negeri Yogyakarta I', At-Tarbawi: Jurnal Kajian Kependidikan Islam, $3.1 \quad$ (2018), <https://doi.org/10.22515/attarbawi.v3i1.1145>.
The Pondok Pesantren Darud Da'wah Wal Irsyad (DDI) Mangkoso held a school education system. During its development since 1989 (leading by AGH. M . Faried Wadjedy), all formal education levels starting from Islamic elementary school (Madrasah Ibtidaiyah) to the higher education had been established. Even, establishing the formal junior high school (SMP), although the Islamic junior high school (MTs) had already built. But, accommodating the national education policies into the Pondok Pesantren DDI Mangkoso education system seems making the students' interest relating to science and technology is higher than the Islamic religious science study.

Furthermore, indeed the Islamic education curriculum in the junior high school do not longer make the kitab kuning as the primary reference due to implement the learning tool according to applicable national education curriculum. This is the concern that the abandoning various agenda of pesantren which is sometimes started from a wish to integrate the national education system and the pesantren education system. The activities of pesantren so dense would impact it because of too many instructional goals that should be reached. Implicating of this reality is the difficulty of focusing to create the desired ideal generations. Studies of Islam have undergone lost direction, and general learning is not optimal $^{10}$.

The happened facts in the Pondok Pesantren DDI Mangkoso signify a struggle between the pesantren's academic that becomes the authority of religious teacher (Kiai) and the national education policy that is accommodated to be implemented in the pesantren education system. These scramble dynamics implicates on eroding the roles of Pondok Pesantren DDI Mangkoso as an

10 Mahpuddin Noor, Potret Dunia Pesantren: Lintasan Sejarah, Perubahan dan Perkembangan Pondok Pesantren (Bandung: Humaniora, 2006), p. 58. 
Islamic study institution. This becomes interesting to be studied, the occurred modernization in the pesantren should only add and complete the roles, without having to crush the main roles that are the fundamental values of establishing it.

Based on the phenomena above, it is important to carry out a research to analyze the dynamics of Pondok Pesantren DDI Mangkoso in accommodating the national education policies by focusing on four main problems such as 1) the existing of Pondok Pesantren DDI Mangokos as a representative of traditional Islamic education institution; 2) the dynamic policies of national education in the period of 1989 to 2018 and its relations to the education policies conducting by the Pondok Pesantren DDI Mangkoso; 3) the varied national education policies accommodating by the Pondok Pesantren DDI Mangkoso, and 4) the varied obstacles of the pesantren in accommodating national education and the solutions.

Types and approaches highly determine the construction of certain research which simplifies the needed data type and the perspective of researchers regarding the discovered data. ${ }^{11}$ Hence, the approach in research is divided into two types namely the methodological approach and scientific approach. This research, methodologically, used a qualitative method through phenomenology approach to finding out sundry phenomena happening in the Pondok Pesantren DDI Mangkoso related to accommodating the national education policy. Data were gathered through observation, interviews, and documentation on informants coming from elements such as leaders, founders, students, and community living surrounding the pesantren. Purposive sampling was taken for this data collection process

11 John W Creswell, Research Design: Qualitative, Quantitative, and Mixed Methods Approaches, 4th edn (California: Sage Publications, 2017), p. 225. (informants were selected by considering their capability in delivering the required data). The found data, scientifically, were analyzed using four scientific approaches namely normative theology, juridic, philosophic, and pedagogic.

After collecting, data were analysis descriptively to figure out the object condition using a certain way and accuracy level for generating beneficially scientific information. ${ }^{12}$ This method was utilized to depict the dynamics of Pondok Pesantren DDI Mangkoso in adjusting the running national education policy when writing up was being taken and checking out the causality of a certain symptom. ${ }^{13}$ Moreover, those data were checked conceptually to dig up the contained meanings of the statements. ${ }^{14}$

The step of analyzing data in this research utilized three tracks of activities which are integrated namely data reduction, interpretation, conclusion. Data reduction is a process of summarizing data according to the main problems having been focused based on themes and patterns. Presenting data was handled in forms of a short description, chart, and relationship among categories, simplifying to understand the happening facts and implicating to the planning works in the future based on what had been understood. The conclusion was an attempt to imply the presented data by involving the researchers understanding. The final conclusion was an answer to the focused problems functioning as the purposes of this research. ${ }^{15}$ Thus, the conclusion had to be positioned on a certain relationship regarding the research focusses. This relationship pattern then was kept looking for and adjusted by the found data

12 Imam Bawani, Metodologi Penelitian Pendidikan Islam (Sidoarjo: Khazanah Ilmu, 2016), p. 344.

13 Suharsimi Arikunto, Prosedur Penelitian: Suatu Pendekatan Praktik (Jakarta: Rineka Cipta, 2010), p. 71.

14 Sudarto, Metodologi Penelitian Filsafat (Jakarta: PT RajaGrafindo Persada, 2007), p. 60.

${ }^{15}$ Sugiyono, Metode Penelitian Kuantitatif, Kualitatif, dan R\&D (Bandung: Alfabeta, 2013), p. 246. 
(phenomena) repeatedly. When this relationship pattern would be accepted based on the gathered data, the result would be able to become a new theory.

\section{The Existence of Pondok Pesantren DDI Mangkoso as A Traditional Islamic Education Institution}

The planning of establishing the Pondok Pesantren DDI Mangkoso was underlaid by the community condition of Soppeng Riaja (one of the sub-districts in Barru Regency, South Sulawesi) at that time which was so minimum of Islamic knowledge. Initiating by Petta Soppeng (The King of Soppeng Riaja), AGH. Abdurrahman Ambo Dalle was brought in in 29 Syawal $1357 \mathrm{H}$ (Islamic Calendar) or December 21, 1938, to lead and manage the Islamic educational institution. That day then was agreed as the born of Pondok Pesantren DDI Mangkoso. In development, although, this institution has managed formal education, however, it never ignores the traditionality in Islamic study.

This indicates three values happening in the education system of Pondok Pesantren DDI Mangkoso such as traditionality, religiosity, and modernity. The use of accumulation term is due to this development does not only transform the pesantren typology but also integrate those three values. In other words, not leaving the value of traditionality after coming to the religion, and also not left the value of religion of modernity is happening. Accordingly, this pesantren is still existing as a traditional Islamic education institution in a modern era.

The accumulation of those values above generates a typology of salafiyah plus, which is an integrated education system of Pondok Pesantren DDI Mangkoso namely combining the traditionalism and modernization in the Islamic educational institution. This integration does not only combine the salaf system and khalaf system, but also confirm the harmonization of identity and openness. This points out that the culture of pesantren as an identity of traditional Islamic education institution forthrightly receiving a modern education system ${ }^{16}$. The culture acceptance of Pondok Pesantren DDI Mangkoso regarding modern education system indicates that this pesantren possesses cultural flexibility. In terms of cultural dynamicity, Islamic universality, and social development are accumulated in an educational institution. The results of this process then are implemented by learning classic Islamic books using the traditional method, and later regularly the classical system (Islamic elementary school and formal school) is improved, and even this classical system is accomplished with learning skills.

The Salafiyah Plus denotes a suppression on the term of salafiyah possessing a plus value. "Salafiyah" clarifies the preserved identity, "plus" expresses an openness for developing in various ways. This means that the Pondok Pesantren DDI Mangkoso is a traditional Islamic education institution historically possessing traditionally roles that ought to be maintained as the characteristics of that institution. In addition, a plus value that makes this institution keeps becoming a choice of community and existing in the modern era modern. In this point, due to it can harmonize and the same time replies the changes and demands of community namely accommodating the national education policy through implementing the classical system affiliating with the Ministry of Religion and the Ministry of Education and Culture.

In terms of having typology, it can be realized that the tradition of the Pondok Pesantren DDI Mangkoso has an elasticity of culture bringing through life and growth in the

16 Suddin Bani, 'Kontribusi Pesantren dalam Sistem Pendidikan Nasional', Auladuna: Jurnal Pendidikan Dasar Islam, 2.2 (2015), 264-73 <http://journal.uinalauddin.ac.id/index.php/auladuna/article/view/881>. 
modern community. This does not emit its characteristics and existence functioning as an institution of Islamic education. It can be figured out through the cultural appliance optimally within other role implementation as demand for modernization. The traditional roles of the Pondok Pesantren DDI Mangkoso being indicators of existence as an institution of Islamic education compose of five components namely 1) a place of transmitting classical Islamic sciences, 2) Da'wah institution, 3) conserving Islamic tradition, 4) centre of generating Muslim scholars, and 5) being a place of community service and development.

First, transmitting classic sciences is taken by learning the "kitab kuning" using a cycle meeting which is not only a tradition but also has been a characteristic denoting the identity of this Islamic boarding school. Indeed, during a year at I'dadiyah (a preparation class for Islamic Junior and Senior High Schools), the students are supplied by an Arabic Language Science (nabwu-saraf) to avoid an overwhelmed condition attending the studying kitab kuning, both general study at the pesantren and integrating into the school curriculum.

Second, the existence of the Pondok Pesantren DDI Mangkoso functions as a Da'wah institution is seen from activities dividing into two objects namely the community internal community inside the school and external community outside the school. Preaching to internal community inside the school meaning the religious leader is helped by some coaches carrying out a certain activity growing the religious awareness of the students or striving those students implementing the proper and correct Islamic teachings consistently ${ }^{17}$. Admonishing to the external community is manifested in the study of classical Islamic books openly for the public in other meaning this event is available for the

17 Dedy Susanto, 'Pesantren dan Dakwah Pemberdayaan Masyarakat Islam', An-Nida: Jurnal Komunikasi Islam, 6.2 (2014), 128-36. public. Furthermore, for this purpose, cooperation took between the Pondok Pesantren DDI Mangkoso and the Religious Affairs Office (KUA) of three surrounding sub-districts namely Soppeng Riaja, Balusu, and Mallusetasi. This cooperation is related to arranging the schedule of Friday Sermon for every mosque at all those three sub-districts. Those mosques are preached by senior religious coaches and some students coming from the Pondok Pesantren DDI Mangkoso.

Third, the Islamic tradition in that pesantren cannot be separated by the culture of surrounding Buginess. This tradition is a product of dialectics between religion perceiving by the Buginess culture reality developing within the community of Mangkoso ${ }^{18}$. This brings up a religiously educative system strongly of Buginess Islamic culture in that pesantren. The framework of the religious educative system of local culturebased is illustrated in the following figure 1.

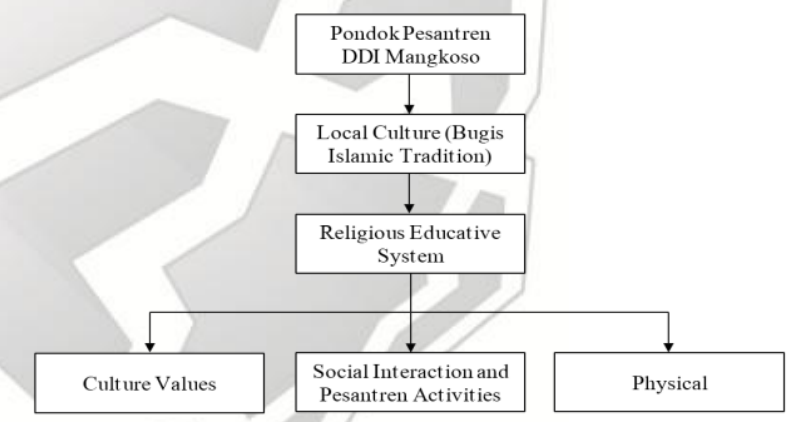

Figure 1. The Religious Educative System of Local Culture-Based

The figure 1 above points out the position of Pondok Pesantren DDI Mangkoso functionating as an Islamic education institution which then generates a religious educative system of local culture-based consisting of three elements such as 1) Culture value, pangadereng (tradition of Buginess) and siri (shame/pride). 2) Social interaction and activities of pesantren, social interactions

18 Ngatawi Al-Zastrouw, 'Mengenal Sepintas Islam Nusantara', Hayula: Indonesian Journal of Multidisciplinary Islamic Studies, $1.1 \quad$ (2017), $1-18$ <https://doi.org/10.21009/hayula.001.1.01>. 
recognizing cultures such as tabe' (permit), greeting puang to gurutta' (religious leader), assipammase-maseng (human solidarity), and sipakatau, sipakainge', sipakalebbi (mutual respect, remind, and praise). Moreover, activities within the Islamic boarding school is seen studying the yellow books, the method of cycling meeting, reciting barzanji, and celebrating some Islamic holidays. 3) Physical, features of buildings and how to dress for students. These three elements have rooted strongly in the community of pesantren, and perceiving and believing their truth, and have been passed down generation to generations.

Forth, not all students are gifted to be religious leaders and willing to be the leaders ${ }^{19}$. However, the Pondok Pesantren DDI Mangkoso is still kept promoting its self as a centre of generating the religious leaders. This can be viewed from that school's implemented curricula and hold formal elementary education. Further, applying the Ma'bad Aly functionates an attempt to create the religious leaders although the no recognition from the Government. Integrating the curricula (between the Islamic boarding school and government) having been conducted is an attempt to generate a plus religious leader such as the religious leaders equipped with affordable science and technology insight or at least scientists with an Islamic background for provision of living either inside or outside that school.

Fifth, regarding the development and service of surrounding communities, this institution has the business of agriculture and animal husbandry that support its economic independence by social entrepreneurship

19 Muammar Kadafi Siregar, 'Pondok Pesantren Antara Misi Melahirkan Ulama dan Tarikan Modernisasi', Jurnal Pendidikan Agama Islam Al-Thariqah, 3.2 (2018), $3>$. system $^{20}$. This is intended those businesses are managed through in collaboration with the surrounding communities to take parts in working at rice fields, raising up livestock, and managing lift nets belonging to that Islamic boarding school. In addition, the numbers of students keep increasing also provide business opportunities for the surrounding communities. This signifies that that pesantren is a center of community development contributing actively in driving the surrounding economic development.

\section{Dynamics of National Education Policy in the Period of 1989-2018}

The national education policy in the period of 1989-2018 undergoes some fluctuations. This delivers a law legitimation on the pesantren position and enhancing its role in the national education. Some of the regulations regarding this are 1) Acts No. 2 of 1989 about National Education System, 2) Acts No. 20 of 2003 about National Education System, and 3) Government Regulation No. 55 of 2007 about Religious Education and Religion Education.

The existence of pesantren has gained legitimation in article 47 of Acts No. 2 of 1989 states as follows; (1) Community as a partner of government has a wide opportunity to participate in the implementation of national education; (2) The characteristics of the education unit implementing by the community are still respected ${ }^{21}$.

That provision above expresses a guarantee position of pesantren as an Islamic education institution that is established and managed by the participation of the community and it is accommodated in the

20 Azel Raoul Reginald and Imron Mawardi, 'Kewirausahaan Sosial pada Pondok Pesantren Sidogiri Pasuruan', Jurnal Ekonomi Syariah Teori dan Terapan, 1.5 (2015), 333-45 <https://doi.org/10.20473/VOL1ISS20145PP\%P>.

${ }^{21}$ Republik Indonesia, Undang-Undang Republik. Indonesia Nomor 2 Tabun 1989 Tentang Sistem Pendidikan Nasional (Jakarta: Badan Standar Nasional Pendidikan, 1989). 
national education system. It is emphasized also in Article 51 that the unit management and educational activity are implementing by communities composing of institutions or individuals for the related educational units ${ }^{22}$. This enables the community independent in managing the Islamic boarding schools based on their characteristics would be implemented.

Entering the era of Acts No. 20 of 2003 about National Education System, the position and existence of pesantren as an educational institution of community-based are not only recognized its existence but also its budget is guaranteed by the government. This position is explained in Article 55 as follows; (1) The community has the right to hold the education of community-based in the formal and nonformal education according to the characteristics of religion, social environment, and culture for communities' interests. ; (2) Implementing education of community-based develops and carries out educational curricula and evaluation, and management as well as budgeting according to the education national standard; (3) The implanting educational budget of community-based can be sourced from the administrators, community, Government, local government and/or other sources which are not against the applicable regulations; (4) The community-based educational institution can get technical assistance, budget subsidies, and other resources fairly and equally from Government and/or local governments ${ }^{23}$.

Furthermore, it is emphasized in Article 15, that educational types cover general, technical, academical, professional, vocational, religious, and special educations. The pesantren, in this case, focusing its education

22 Republik Indonesia, Undang-Undang Republik Indonesia Nomor 2 Tabun 1989 Tentang Sistem Pendidikan Nasional.

${ }^{23}$ Republik Indonesia, Undang-Undang Republik Indonesia Nomor 20 Tabun 2003 Tentang Sistem Pendidikan Nasional (Jakarta: Direktorat Pendidikan Menengah Umum, 2003). domain in the field of religion. The term of "Pesantren" is mentioned in the typical explanation regarding the provision of religious education of Article 30 as follows; (1) Religious education is implemented by Government and/or community groups from adherents of religion according to the applicable regulations; (2) Religious education functionates providing students to be community members who understand and practice their religious values and/or becoming theologians; (3) Religious education can be implemented in the tracts of formal, non-formal, and informal education; (4) Religious education is in forms of diniyah, pesantren, pasraman, pabhaja samanera, and other similar forms ${ }^{24}$.

That regulation denotes that the pesantren in one hand is an educational institution, and another hand, religious education can be implemented in all tracks of education. Therefore, in this regulation, the Islamic boarding school is granted a privilege to manage education at all tracks of education (formal, non-formal, and informal education forms).

The pesantren in the Government Regulation No. 55 of 2007 about Religious Education and Religion Education is defined as a community-based education institution of Islamic Religion that implements a diniyah education or integrated with other education types $^{25}$. So, in its development, the pesantren does not only function as a merely Islamic religious education institution but also has opened up to perform an education of integrating the diniyah (religion) and not-diniyab (general) ${ }^{26}$. This slot is accommodated in

${ }^{24}$ Republik Indonesia, Undang-Undang Republik Indonesia Nomor 20 Tabun 2003 Tentang Sistem Pendidikan Nasional.

25 Republik Indonesia, Peraturan Pemerintah Republik Indonesia Nomor 55 Tahun 2007 Tentang Pendidikan Agama dan Pendidikan Keagamaan (Jakarta: Kemenag, 2007).

26 Ali Muzakir, 'Transformasi Pendidikan Islam di Jambi: Dari Madrasah ke Pesantren', Islam Realitas: Journal of Islamic \& Social Studies, 3.1 (2017), 8- 
Article 14 stating as the following items; (1) Islamic religious education is in the form of diniyah and pesantren; (2) The diniyah education as mentioned in the verse (1) is administrated in the tracks of formal, nonformal, and informal; (3) The pesantren can perform one (1) or varied units and/or educational programs in the tracks of formal, non-formal, and informal ${ }^{27}$.

That regulation is very accommodativeness and relevance to the development of Islamic boarding schools currently. In reality, more pesantren open up various formal (general) education units that are complemented by sundry non-formal educations. In this stage, the students of those schools are educated, guided, and trained to possess life skills compatible with each students' interests and talents. No exception, the Pondok Pesantren DDI Mangkoso also has carried out the same matter. Hence, the pesantren, basically, is not only functioned as an Islamic educational institution, currently, but also plays an important role in performing the education institution. Therefore, the is a shift happening of pesantren position wider as an Islamic education institution and also as a community organization engaging in the educational field or a foundation performing an education system.

Nevertheless, the pesantren had experienced institutional positioning shift, but its major components composing of various characteristics are still maintained. In fact, this is fully guaranteed in the Government Regulation No. 55 of 2017 in Article 12 verse (2), that the government protects independence and distinctiveness of religious

20

<https://doi.org/http://dx.doi.org/10.30983/islam_re alitas.v3i1.212>.

27 Republik Indonesia, Peraturan Pemerintah Republik Indonesia Nomor 55 Tahun 2007 Tentang Pendidikan Agama dan Pendidikan Keagamaan (Jakarta: Kemenag, 2007). education since it is not against the national education goals. $^{28}$

Securing the independence and peculiarity of religious education by the government should make the pesantren, not an allergy in touching the global civilisation. The pesantren needs a critical attitude in order to still survive in this modern era without eliminating its tradition and wisdom.29 For that reason, the status as a traditional Islamic education institution still exists even though its development is in a modern way.

Based on the formulation of national education policy in the period of 1989 to 2018 and the position of pesantren within the policy, when this policy is implemented in the educational policy in the Pondok Pesantren DDI Mangkoso, the arising dynamics are divided into three stages namely institutional transformation, curriculum guidance, and implementation of culture-based inclusive paradigm.

The institutional transformation conducting by the Pondok Pesantren DDI Mangkoso is highly related to social transformation. The presence of this transformation in the Islamic schools/general schools is an entity of attempting to fulfil the community needs regarding more complexities of education institutions $^{30}$. Issuing the Acts No. 2 of 1989 about National Education System and then was reinforced by Acts No. 8 of 1985 about Social Organization starts a new phase of institutional positioning of Pondok Pesantren DDI Mangkoso to be stronger. This underlies the willingness of that school in the last $80 \mathrm{~s}$

${ }^{28}$ Republik Indonesia, Peraturan Pemerintah Republik Indonesia Nomor 55 Tahun 2007 Tentang Pendidikan Agama dan Pendidikan Keagamaan (Jakarta: Kemenag, 2007).

29 Abdurrahman Wahid, Menggerakkan Tradisi: Esai-esai Pesantren (Yogyakarta: LKiS, 2010), p. 68.

30 Husmiaty Hasyim, 'Transformasi Pendidikan Islam (Konteks Pendidikan Pondok Pesantren)', Jurnal Pendidikan Agama Islam -Ta'lim, 13.1 (2015), 57-77. 
(the beginning of establishing directed by AGH. M. Faried Wadjedy to administer the formal education institution by preserving the cultural characteristics of pesantren including the formal education unit teaching that is developed. Furthermore, setting up and managing the private Islamic schools/general schools according to the applicable regulations has to be taken by social organization or foundation. The occurred institutional transformation of Pondok Pesantren DDI Mangkoso starts from education and preaching institution to become a social organization engaging in the field of Islamic education. Thus, the Pondok Pesantren DDI Mangkoso can establish and organise the education institution in various types and tracks as completing the Islamic education which is the main purpose domain of this organisation.

Previously each student who was studying in Mangkoso had to follow a lame/segregated class (multi-classes). For instance, a student who was in the general junior high school class at the same time she/she should be a student in the religious elementary class. This condition made the student would not be graduated at the same time. After transforming the institution, the lame class system in that school was eliminated and changed by a formal education institution using the integrated curricula combining the pesantren curriculum (kitab kuning) and national education curriculum (government). The policy leading by AGH. M. Faried Wadjedy is not without any obstacles. His paradigm that was non-dichotomic between the religious science and general science offered in the beginning was protested by several senior religious leaders who managed that pesantren. Opening up the integrated school system with the higher general subjects was worried would make this pesantren loss of planning to be the centre of Islamic science quality and also was assumed to decrease due to being being limited on times with dense schedules.

Worries from those religious scholars were not blamed by Wadjedy, because of the mentioned risks, of course, would be happened if this policy was carried out without any good preparation steps and sustainable development. Factually, transformation social is still occurring, and the pesantren has to respect on the appearing modernity aspects in order to the traditionality of pesantren can be received by communities nowadays. The integrated curricula implemented in the Pondok Pesantren DDI Mangkoso is not meant abandoning the traditionality side of that school. The students who are in both the Islamic school and the general school compulsory attending a daily activity of cycling meeting learning (studying the kitab kuning).

To avoid the incompetence of students following the religious subjects in the integrated school originating from the kitab kuning, the Pondok Pesantren DDI Mangkoso opens a preparation class "Madrasah I'dadiyah" for entering the integrated school. For a year, the students of class "I'dadiyah" were tough a methodological science such as nahwu, saraf, and Arabic language every day. It is expected the graduates of I'dadiyah with their knowledge can keep up well the lessons in that school (madrasab) and enable to complete their study in the same time with a similar quality, and more efficient learning time.

Improvement efforts in designing and defining the education policy leading to an ideal format of the education system for the Pondok Pesantren DDI Mangkoso still continues by applying a culture-based inclusive paradigm. This can be looked at the education policy of the Pondok Pesantren DDI Mangkoso that maintains its Islamic boarding school characteristics, meet the community needs, and implement the government demands. For more detail regarding culturebased inclusive paradigm constructing the 
Pondok Pesantren DDI Mangkoso is illustrated as the following figure 2 .

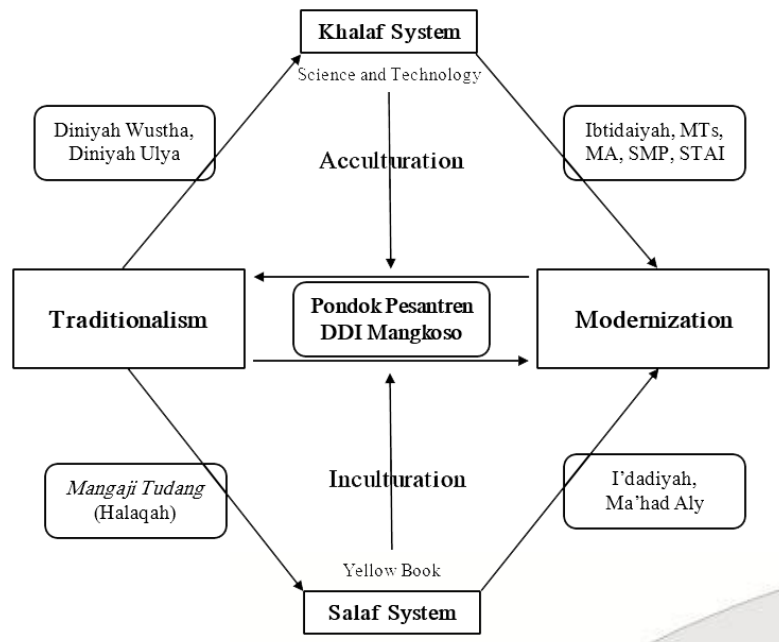

Figure 2. Pesantren Culture-Based Inclusive Paradigm

The inclusive paradigm as illustrating on the figure above is supported by some institutions such as I'dadiyah, Ma'bad Aly, and Non-formal Diniyah. Even though has been formed as a school (classical system), however the kitab kuning curriculum and its distinguishing method still dominate the learning process of those institutions. The curriculum and method are remains of predecessors in the Pondok Pesantren DDI Mangkoso functionating as the characteristics which keep being preserved and hoped capable to accompany its students mastering the Islamic religious sciences. Starting from this point, the inculturation process occurs between the Islamic value (within the learning materials of kitab kuning) which becomes a part of local culture in that pesantren.

Moreover, the results of acculturation also can be noticed in various formal education institution of the Pondok Pesantren DDI Mangkoso. The general science learned in those formal education institutions let the students thinking globally. These institutions always are developed by the modernity spirit which is based on local culture. This spirit can be viewed from implementing the curriculum integrating the pesantren curriculum and the national education curriculum in that formal institution. This process generates a distinctive curriculum and different from other formal Islamic/general formal schools. No dichotomizing the religion science and general science in the pesantren learning. This allows integration and synchronization between the religion and general science which makes the interaction between them.

Students in the Ma'bad $A l y$ are required to participate actively in the critical thinking of Islam to respond and reply to all developing problems within the communities. Proving by academic final results of its graduates that appeared themes regarding contemporary fiqh, interpretation, and religious thought. Indeed, it is important to be paid attention and responses typically from intellectual Muslim. Their works were written in the straightforward, critical, and pithy languages. Unfortunately, those varied works are not supported by a good publication implicating to the public does not access these beneficial works yet. The Pondok Pesantren DDI Mangkoso should provide a portal or website accommodating these various academic works in order to varied thoughts related to contemporary problems can be consumed by the public.

Varied National Education Policy Accommodating by Pondok Pesantren DDI Mangkoso

\subsection{Classical System Management}

The most prominent features of national education policy accommodating by the Pondok Pesantren DDI Mangkoso is an opening up of classical education system affiliating with the Ministry of Religion (Ibtidaiyah, MTs, and $M A$ ), and the Ministry of Education and Culture Junior High School, $S M P)$. This opening of Islamic and general education system is a proof of readiness for the Pondok Pesantren DDI Mangkoso by implementing the Government Regulation No. 13 of 2015 that revised from the 
Government Regulation No. 19 of 2005 about the Education National Standard in managing the formal education institution. Therefore, aspects of the curriculum, learning process, graduate competency, educator, educational staff, infrastructure, management, budgeting, and assessing of Islamic/general schools, should comply the national standard qualification and openly accepting the policy change, monitoring, and evaluation from the government $^{31}$.

This acceptance pushing the classical system management in the Pondok Pesantren DDI Mangkoso assigns the older religious leaders in an improper determining position of policy singly ${ }^{32}$. The classical institution management (formal) is perceived to the organization leading by the school headmaster. Though the role of elder religious leaders is still viewed important, their authority has distributed to the policies issuing by the government as the headmasters of Islamic/general schools ${ }^{33}$.

The classical institutions affiliating with the Pondok Pesantren DDI Mangkoso apply pesantren-based Madrasah management. This is due to the Madrasah is under guided by the pesantren which means activities of Madrasah are pesantren activities. This management system contains a meaning the authority and responsibility in the Madrasah level to make decisions relating to the education implementation is suitable with the defined framework issuing by the government in the frame of the pesantren system ${ }^{34}$. It has three

31 Siswanto Siswanto, 'Madrasah Unggulan Berbasis Pesantren', Ulumuna, 18.1 (2014), 159-80 <https://doi.org/10.20414/ujis.v18i1.157>.

32 Moh Afiful Hair, 'Reformulasi Pendidikan Pesantren dalam Dialektika Konteks Masyarakat Global', Tadris: Jurnal Pendidikan Islam, 12.1 (2017), 92104 < https://doi.org/10.19105/tadris.v12i1.1288>.

33 Siswanto.

34 Asbin Pasaribu, 'Implementasi Manajemen Berbasis Sekolah dalam Pencapaian Tujuan Pendidikan Nasional di Madrasah', EduTech: Jurnal Ilmu Pendidikan Dan Ilmu Sosial, 3.1 (2017), 12-34. principles namely responsible independence, cooperation and participation from all parties, and transparent and accountable administration. These principles underlie the classical system management in the Pondok Pesantren DDI Mangkoso. The mechanism of these principles is based on the education management standard regulated in the Ministry Regulation of National Education No. 9 of 2007, covers five aspects such as planning programs, implementing work plan, controlling and evaluating school leadership, and managing information system.

\subsection{National Education Curriculum}

The pesantren-based Madrasah management brings about an integrated curriculum, namely implementing both the national education and the pesantren curriculum completely ${ }^{35}$. In other word, the conducted national education curriculum is adjusted with the affiliating Ministry's education unit. The Madrasah is matched to the curriculum coming from the Ministry of Religion, and the formal school is set with the curriculum of the Ministry of Education and Culture. Furthermore, the curriculum of pesantren is not only local content but also possesses the additional lesson hours for specific subjects such as fiqih, akidah akblak, alQur'an, hadith, tafsir, linguistics of Arabic, falaq and faraid in the effective hours of Madrasah or school.

This absolutely makes the schedule of students very tight. However, it is going to furnish the intellectual, emotional, and spiritual experiences needed by the students. The Madrasah curriculum in the pesantren cover art, science, and religion as a must

${ }^{35}$ See, Nawali. Compare with Ardian Asyhari, Rumadani Sagala, and Iin Kendedes, 'Respon Pondok Pesantren Diniyyah Putri terhadap Modernisasi Pendidikan Islam', Tadris: Jurnal Pendidikan Islam, 12.2 (2017), 232-42 <https://doi.org/10.19105/tipi.v12i2.1505>. 
component, both individual and groups of the community ${ }^{36}$.

\subsection{Learning Process Standardization}

The government through the Decree of the Minister of Education and Culture No. 5 of 2013, defines criteria of learning process implementation in an education unit to achieve the graduating standards nationally. These criteria consist of implementing the learning interactively, imperatively, enjoyably, challengeable, motivating the students to actively participated, and providing enough rooms for being initiative, creative, and independent in according with the talents, interests, and physical and psychological development of students ${ }^{37}$.

Unfortunately, the learning curriculum of pesantren in the madrasah still uses student centre learning by a conventional (traditional) method though it is carried out in a classical system. No learning tools still rely on the memorization method without any varied method. So, this only moves the learning place from the mosque to the madrasah, without any improvement in terms of the learning method.

Looking at this problem, it is important for the Pondok Pesantren DDI Mangkoso to set a drafting team of the curriculum in order to simplify the taught materials in the yellow books to the madrasah. This process will build hopefully intended purposes and indicators requiring at the end of learning. Hence, the curriculum of the kitab kuning in the madrasah has a complete educational administration as required by the government due to it is included in a subject of the madrasah.

\subsection{Standardization of Educators}

An incompleteness of educational administration of the pesantren curriculum

\footnotetext{
36 Siswanto.

37 Republik Indonesia, Peraturan Menteri Pendidikan dan Kebudayaan Nomor 65 Tahun 2013 Tentang Standar Proses (Jakarta: Depdikbud, 2013).
}

subjects in the Islamic elementary school (madrasah) is caused by educators, in general, teaching the curriculum of pesantren are the Islamic law scholar (sharia). These teachers are not equipped with pedagogic competencies through the education process, however, only based on the teaching experiences and learning in the pesantren. Oppositely, the educators (teachers) teaching the subjects of government curricula have fulfilled the educator criteria based on the Acts No. 14 of 2005 about Teacher and Lecturer and carrying out teaching as the learning process standard. It is a product of standardizing the educators and education administrators nationally, and an obligation of reporting national education primary data online-based gradually. This mechanism only receives data of educators meeting the requirements according to Acts No. 14 of 2005.

Varied Obstacles Facing by Pondok Pesantren DDI Mangkoso in Accommodating the National Education Policy

The organizational culture of pesantren naming as barakeka' (blessing) and madoraka (insubordinate) makes a difficulty of the headmaster of Madrasah doing management structurally. Gurutta' (elder religious leader) as a subject teacher is difficult to be directed in terms of administrative requirements and learning process implementation referring to the Government Regulation No. 13 of 2015 about the National Standard of Education. In fact, matters regarding education policy highly underlie to the proposers. The headmaster of Madrasah usually discusses that matter relating to a change of education policy to the gurutta' privately before holding the Madrasah meeting. The discussion is an attempt to asking for permit and blessing upon the change of education policy requiring by the government which should be implemented in the Madrasah. Furthermore, a meeting agreement substantially is the government 
regulation, however, it is essentially a willingness of gurutta'. This occurs a pedagogic-etic communication between the headmaster and the gurutta'. Structurally, the gurutta' is his/her subordinate but culturally is his/her teacher ${ }^{38}$.

Devoting without limits by the gurutta' who are reading being a subject teacher due to the regeneration of educators willing to dedicate to his/her alma mater is still low that implicates to some subjects in terms of pesantren curriculum is still lack of teachers. The limited resources both quality and quantity makes the teachers are not methodological in the learning process ${ }^{39}$. Teachers at most utilize a lecture method, focus on memorizing than reasoning, and even an educator teaches more than one subject or far of his/her expertise. For that reason, the Pondok Pesantren DDI Mangkoso should recruit educators fulfilling both the criteria standard of national education policy and the pesantren. This is intended to meet the learning curriculum of pesantren in the Madrasah suitable with the standard of learning process nationally. A successful process of learning in the varied modern methods as an attempt to meet the graduate standard which is highly affected by educational facilities 40. Unluckily, the educational facility-technology based is still minimum. This condition surely has to be a developing program in the future and becomes the attention of all parties. In the reality, community (student parents and

${ }^{38}$ See Suparjo. Compare with Akmaluddin Mulis and Daniel Caniago, 'Pola Jaringan Guru Murid Syeikh Haji Ali Imran Hasan Pondok Pesantren Nurul Yaqin Ringan - Ringan dari 1970-2010', Islam Realitas: Journal of Islamic \& Social Studies, $4.1 \quad$ (2018), 65 <https://doi.org/10.30983/islam_realitas.v4i1.705>.

39 Leonard Leonard, 'Kompetensi Tenaga Pendidik di Indonesia: Analisis Dampak Rendahnya Kualitas SDM Guru dan Solusi Perbaikannya', Formatif: Jurnal Ilmiah Pendidikan MIPA, 5.3 (2016), 192-201 <https://doi.org/10.30998/formatif.v5i3.643>.

40 Azhar Arsyad, Media Pembelajaran Edisi Revisi (Jakarta: Rajawali Pers, 2017), p. 3. surrounding people) do not possess any bigger role in planning, actuating, monitoring, and evaluating the educational programs of the pesantren including in point of programs of technological uses in learning. Ideally, the traditionality of pesantren should not be an obstacle in mastering science and technology. Therefore, the educational technology in the pesantren has to be programmed by supporting coming from government and community participation in the planning, actuating, and evaluating the process to rise up the responsibility of all parties for its successful.

\section{Conclusion}

Based on the research results and discussion describing previously, the conclusion of this research is listed as follows. First, even though, the development of Pondok Pesantren DDI Mangkoso is modern, however it is still existing as a traditional Islamic education institution by preserving five roles such as a transiting place of classical Islamic sciences, Islamic missionary endeavour institution, conserving the Islamic tradition, centre of generating Muslim scholars, and institution of community development and service. Second, the dynamics of national education policy in the period of $1989-2018$ implicate on the position of pesantren in relating to the national education system and possess a correlation to the education policy conducting in the Pondok Pesantren DDI Mangkoso that its development divided into three steps namely institutional transformation, curriculum guidance, and implementing inclusive paradigm of culturebased. Third, the accommodation forms of national education policy carried out by the Pondok Pesantren DDI Mangkoso are classical system management, national education curriculum implementation, learning process standardization, and educator standardization. Fourth, sundry obstacles facing 
by the Pondok Pesantren DDI Mangkoso in adjusting the struggle of culture and organizational structure, limited resources, and low community participation.

According to this conclusion, perceiving assumption here is an accommodation of national education policy in the Pondok Pesantren DDI Mangkoso implicates to its role getting more widely. The existence of pesantren as a representative of Islamic education institution should be based on optimizing its traditional roles. Hence, the happening role reposition of Pondok Pesantren DDI Mangkoso is getting widely as accumulating values of traditionality, religiosity (Islam), and inclusively modernity. This accumulation yields typology of Salafiyah Plus expressing the traditionality of pesantren that is willing to receive a modern education system for fulfilling the needs of community development. Therefore, a pesantren as a traditional Islamic education institution has to possess three characteristics, namely 1) Contextual; implementing education in accordance with changing times, and fast responding on change demands. 2) Progressive; the progress of times is not recognized as threats on traditionality, but it is looked like a trigger to respond creativities intensely. 3) Liberation; becomes an education institution allowing to answer the human problems universally. Accordingly, the pesantren is not stagnant in dealing with the social reality of community which is always changing.

The social change of community also goes along impacting on the development of Islamic boarding school. The policy changes of national education in the period of 19892018 contribute to the institutional position of pesantren in the national education which is getting strong. Applying inclusive paradigm of culture-based in the Pondok Pesantren DDI Mangkoso generates an accommodation of sundry national education policies that are seen in the formal education institution management at all education levels both affiliating with the Ministry of Religion and incorporating with the Ministry of Education and Culture. This paradigm implementation should be based on the Government Regulation Number 13 of 2015 about Education National Standard.

The Pondok Pesantren DDI Mangkoso in realizing its all education programs regarding accommodating the national education policy is not without any obstacles. Some problems are encountering by the Pondok Pesantren DDI Mangkoso as obstacles in thriving to accommodate the policy above. However, the local culture of the pesantren breathing of Islam can be strength of development and also completing by supporting from government and community which therefore become solutions of those problems heading to be an ideal pesantren [accumulating of local culture (pesantren tradition), demands of government, and community needs in the education system of pesantren]. But, the Pondok Pesantren DDI Mangkoso needs to look our on the state domination as a result of accommodating the national policy enabling probably shifting the educational orientation of the pesantren from values to the state formalistic goals.

\section{References}

\section{Books}

Arikunto, Suharsimi, Prosedur Penelitian: Suatu Pendekatan Praktik (Jakarta: Rineka Cipta, 2010)

Arsyad, Azhar, Media Pembelajaran Edisi Revisi (Jakarta: Rajawali Pers, 2017)

Bawani, Imam, Metodologi Penelitian Pendidikan Islam (Sidoarjo: Khazanah Ilmu, 2016)

Creswell, John W., Research Design: Qualitative, Quantitative, and Mixed Methods Approaches, 4th edn (California: Sage Publications, 2017) 
Dhofier, Zamakhsyari, Tradisi Pesantren: Studi Pandangan Hidup Kyai dan Visinya Mengenai Masa Depan Indonesia (Jakarta: LP3ES, 2015)

Haederi, M. Amin, Masa Depan Pesantren: Dalam Tantangan Modernitas dan Tantangan Kompleksitas Global (Jakarta: IRD Press, 2006)

Ma'arif, Syamsul, Pesantren Inklusif Berbasis Kearifan Lokal (Yogyakarta: Kaukaba Dipantara, 2015)

Madjid, Nurcholish, Bilik-bilik Pesantren: Sebuah Potret Perjalanan (Jakarta: Dian Rakyat dan Paramadina, 2010)

Noor, Mahpuddin, Potret Dunia Pesantren: Lintasan Sejarah, Perubahan dan Perkembangan Pondok Pesantren (Bandung: Humaniora, 2006)

Soebahar, Abd Halim, Modernisasi Pesantren: Transformasi Kepemimpinan Kiai dan Sistem Pendidikan Pesantren (Yogyakarta: LKiS, 2013)

Sudarto, Metodologi Penelitian Filsafat (Jakarta: PT RajaGrafindo Persada, 2007)

Sugiyono, Metode Penelitian Kuantitatif, Kualitatif, dan R\&DD (Bandung: Alfabeta, 2013)

Wahid, Abdurrahman, Menggerakkan Tradisi: Esai-esai Pesantren (Yogyakarta: LKiS, 2010)

\section{Journals}

Al-Zastrouw, Ngatawi, 'Mengenal Sepintas Islam Nusantara', Hayula: Indonesian Journal of Multidisciplinary Islamic Studies, 1 (2017), 1-18 $<$ https://doi.org/10.21009/hayula.001.1. 01>

Asyhar, Ali, 'Model Transformasi Pendidikan Pondok Pesantren di Pulau Bawean Gresik', JOIES: Journal of Islamic Education Studies, 1 (2016), 277-302

Asyhari, Ardian, Rumadani Sagala, and Iin Kendedes, 'Respon Pondok Pesantren Diniyyah Putri terhadap Modernisasi Pendidikan Islam', Tadris: Jurnal Pendidikan Islam, 12 (2017), 232-42
$<$ https://doi.org/10.19105/tjpi.v12i2.15 05>

Bani, Suddin, 'Kontribusi Pesantren dalam Sistem Pendidikan Nasional', Auladuna: Jurnal Pendidikan Dasar Islam, 2 (2015), 264-73 <http://journal.uinalauddin.ac.id/index.php/auladuna/articl e/view/881>

Caldas, Miguel Pinto, Research Design: Qualitative, Quantitative, and Mixed Methods Approaches, Revista de Administração ContemporâNea, 4th edn (California: Sage Publications, 2003), VII $<$ https:// doi.org/10.1590/s141565552003000100015>

Fauzi, Ahmad, 'Pendidikan Inklusif Berbasis Kearifan Lokal dalam Praktik Sosial di Pesantren Zainul Hasan Genggong Probolinggo Jawa Timur', in Proceedings of Annual Conference for Muslim Scholars, 2017, pp. 715-25

Hair, Moh Afiful, 'Reformulasi Pendidikan Pesantren dalam Dialektika Konteks Masyarakat Global', Tadris: Jurnal Pendidikan Islam, 12 (2017), 92-104 $<$ https://doi.org/10.19105/tadris.v12i1. $1288>$

Hasan, Muhammad, 'Inovasi dan Modernisasi Pendidikan Pondok Pesantren', Karsa: Journal of Social and Islamic Culture, 23 (2015), 296-306 <https://doi.org/10.19105/karsa.v23i2.7 $28>$

Hasyim, Husmiaty, 'Transformasi Pendidikan Islam (Konteks Pendidikan Pondok Pesantren)', Jurnal Pendidikan Agama Islam -Ta'lim, 13 (2015), 57-77

Jamal, Nur, 'Transformasi Pendidikan Pesantren dalam Pembentukan Kepribadian Santri', Tarbiyatuna: Jurnal Pendidikan Islam, 8 (2015), 64-100

Kesuma, Guntur Cahaya, 'Refleksi Model Pendidikan Pesantren dan Tantangannya Masa Kini', Tadris: Jurnal Keguruan Dan Imu Tarbiyah, 2 (2017), 67 $<$ https://doi.org/10.24042/tadris.v2i1.1 $740>$ 
Leonard, Leonard, 'Kompetensi Tenaga Pendidik di Indonesia: Analisis Dampak Rendahnya Kualitas SDM Guru dan Solusi Perbaikannya', Formatif: Jurnal Ilmiah Pendidikan MIPA, 5 (2016), 192 201

<https://doi.org/10.30998/formatif.v5i3 $.643>$

Mulis, Akmaluddin, and Daniel Caniago, 'Pola Jaringan Guru Murid Syeikh Haji Ali Imran Hasan Pondok Pesantren Nurul Yaqin Ringan - Ringan dari 1970-2010', Islam Realitas: Journal of Islamic \& Social Studies, $\quad 4 \quad$ (2018), $\quad 65$ $<$ https://doi.org/10.30983/islam_realita s.v4i1.705>

Muzakir, Ali, 'Transformasi Pendidikan Islam di Jambi: dari Madrasah ke Pesantren', Islam Realitas: Journal of Islamic \& Social Studies, 3 (2017), $\quad 8-20$ $<$ https://doi.org/http://dx.doi.org/10.3 0983/islam_realitas.v3i1.212>

Nawali, Ainna Khoiron, 'Dampak Penerapan Kurikulum Kementerian Agama dan Kurikulum Pesantren terhadap Peningkatan Hasil Belajar Pendidikan Agama Islam di Madrasah Aliyah Negeri Yogyakarta I', At-Tarbawi: Jurnal Kajian Kependidikan Islam, 3 (2018), 13 $<$ https://doi.org/10.22515/attarbawi.v3i $1.1145>$

Pasaribu, Asbin, 'Implementasi Manajemen Berbasis Sekolah dalam Pencapaian Tujuan Pendidikan Nasional di Madrasah', EduTech: Jurnal Ilmu Pendidikan dan Ilmu Sosial, 3 (2017), 12-34

Reginald, Azel Raoul, and Imron Mawardi, 'Kewirausahaan Sosial pada Pondok Pesantren Sidogiri Pasuruan', Jurnal Ekonomi Syariah Teori dan Terapan, 1 (2015), $333-45$ $<$ https://doi.org/10.20473/VOL1ISS20 $145 \mathrm{PP} \% \mathrm{P}>$

Saifuddin, Ahmad, 'Eksistensi Kurikulum Pesantren dan Kebijakan Pendidikan', Jurnal Pendidikan Agama Islam Journal of Islamic Education Studies), 3 (2016), 207 $<$ https://doi.org/10.15642/pai.2015.3.1. 207-234>
Siregar, Muammar Kadafi, 'Pondok Pesantren antara Misi Melahirkan Ulama dan Tarikan Modernisasi', Jurnal Pendidikan Agama Islam Al-Thariqah, 3 (2018), 16 <https://doi.org/10.25299/althariqah.20 18.vol3(2).2263>

Siswanto, Siswanto, 'Madrasah Unggulan Berbasis Pesantren', Ulumuna, 18 (2014), 159-80 <https://doi.org/10.20414/ujis.v18i1.15 $7>$

Suparjo, 'Relasi Kiai-Santri di Pesantren Futuhiyyah, Demak', Ibda': Jurnal Kajian Islam dan Budaya, 15 (2017), 192-214 <https://doi.org/10.24090/IBDA.V15I $2.1335>$

Susanto, Dedy, 'Pesantren dan Dakwah Pemberdayaan Masyarakat Islam', $A n$ Nida: Jurnal Komunikasi Islam, 6 (2014), 128-36

\section{Other references}

Republik Indonesia, Peraturan Menteri Pendidika dan Kebudayaan Nomor 65 Tabun 2013 Tentang Standar Proses (Jakarta: Depdikbud, 2013)

Peraturan Pemerintah Republik Indonesia Nomor 55 Tabun 2007 Tentang Pendidikan Agama Dan Pendidikan Keagamaan (Jakarta: Kemenag, 2007)

, Undang-Undang Republik Indonesia Nomor 2 Tabun 1989 Tentang Sistem Pendidikan Nasional (Jakarta: Badan Standar Nasional Pendidikan, 1989)

-, Undang-Undang Republike Indonesia Nomor 20 Tabun 2003 Tentang Sistem Pendidikan Nasional (Jakarta: Direktorat Pendidikan Menengah Umum, 2003) 